\title{
The Risk of Antihypertensive Drug among Breast Cancer Patient: A Systematic Review and Meta-analysis
}

Sinta Wiranata ${ }^{1}$ (D), Ida Ayu Widya Anjani ${ }^{1}$, Putri Ayu Wulandari ${ }^{1}$, Anak Agung Bagus Putra Indrakusuma ${ }^{1}$, I Gede Krisna Arim Sadeva ${ }^{1}$, Ayu Dilia Febriani Wisnawa ${ }^{1}$, Jonny Karunia Fajar ${ }^{2}$, I Putu Yuda Prabawa ${ }^{3}$, Putu Anda Tusta Adiputra $^{4}$, I Wayan Sudarsa ${ }^{4}$ (D), Anak Agung Wiradewi Lestari ${ }^{3}$, Desak Made Wihandani ${ }^{5}$ (D) I Gede Putu Supadmanaba ${ }^{5}$

${ }^{1}$ Medical Student, Faculty of Medicine, Universitas Udayana, Denpasar, Bali, Indonesia; ${ }^{2}$ Department of Internal Medicine, Brawijaya Internal Medicine Research Center, Faculty of Medicine, Universitas Brawijaya, Malang, East Java, Indonesia; ${ }^{3}$ Department of Clinical Pathology, Faculty of Medicine, Universitas Udayana, Sanglah General Hospital, Denpasar, Bali, Indonesia; ${ }^{4}$ Department of Surgery, Division of Surgical Oncology, Faculty of Medicine, Universitas Udayana, Sanglah General Hospital, Denpasar, Bali, Indonesia; ${ }^{5}$ Department of Biochemistry, Faculty of Medicine, Universitas Udayana, Denpasar, Bali, Indonesia

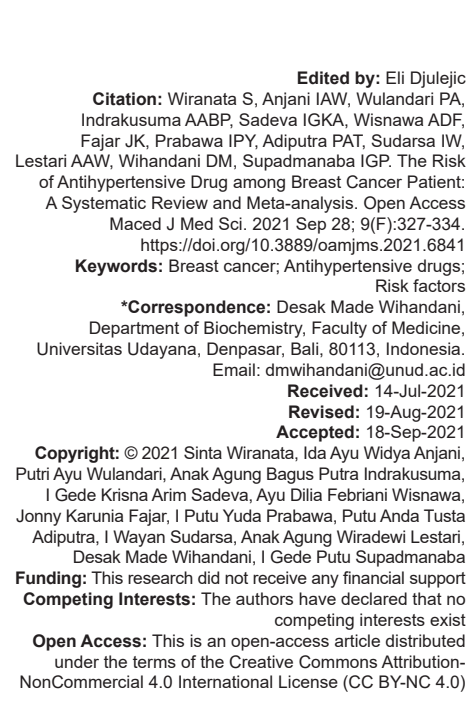

\section{Abstract}

BACKGROUNDS: Breast cancer or breast carcinoma is the most common type of malignancy in women globally According to the previous studies that indicate the usage of antihypertensive drugs may become a risk factor of cancer (beta-blockers [BBs], calcium channel blockers [CCBs], and diuretics). Both angiotensin-converting enzymes inhibitors (ACEIs) and angiotensin II receptor blockers (ARBs), on the other hand, have been associated to an increased or decreased risk of breast cancer

AIM: To compare each type of antihypertensive medicines as a risk factor for breast cancer, we did a systematic review and meta-analysis of current evidence.

METHODS: We utilized the terms "antihypertensive", "anti-hypertensive", "anti-hypertensive medications", "breas cancer", "risk", "case control", and "cohort" in PubMed, ScienceDirect, and Google Scholar databases.

RESULTS: Our data calculation found that the risk of antihypertensive drugs was significantly different in overal analysis (odds ratio $[\mathrm{OR}]=0.59,95 \%$ confidence interval $[\mathrm{Cl}]=0.42-0.83, \mathrm{p}=0.003$ ). Five studies with 39.503 breast cancer patients and 372.037 controls were included in the ARBs user sub-group. Our results found significant different of antihypertensive drugs among breast cancer patient $(\mathrm{OR}=1.47,95 \% \mathrm{Cl}=1.02-2.11 \mathrm{p}=0.04)$. Our data calculation also confirmed no significant different in antihypertensive drugs among breast cancer patient $(\mathrm{OR}=1.07$ $95 \% \mathrm{Cl}=0.99-1.16, \mathrm{p}=0.09)$ in diuretics user, $(\mathrm{OR}=1.08,95 \% \mathrm{Cl}=0.99-1.18, \mathrm{p}=0.08)$ in $\mathrm{CCBs}$ user, $(\mathrm{OR}=1.11$, $95 \% \mathrm{Cl}=0.98-1.26, p=0.09)$ in $\mathrm{BBs}$ user, and $(\mathrm{OR}=1.27,95 \% \mathrm{Cl}=0.64-2.50, \mathrm{p}=0.50)$ in ACEls user.

CONCLUSIONS: Although, the finding reveal that antihypertensive drugs (diuretics, CCBs, BBs, and ACEls) in overall are significant for the risk of breast cancer and also found that ARBs have a low potential in the risk of breas cancer.

\section{Introduction}

Hypertension is one of the world's most common diseases [1], [2]. It has a high prevalence, impacting 9.4 billion people worldwide [3], [4], resulting in millions of deaths and a one-billion-person morbidity [5]. Antihypertensive agent is the most common intervention or treatment for this disease that commonly prescribed by doctor to help avoid adverse effects of hypertension such as stroke, insufficient heart, coronary heart disease, and other cardiovascular disease. The total finished prescriptions achieved in 2010 as many as 6782 million in United States of America (USA) alone [6].

The antihypertensive drug is classified or divided into some groups. The groups have some unique mechanisms and pathway that related to the specific receptor and ligan in suppressing hypertension condition (a variety of pathophysiological issues). The most used pharmacological groups used are diuretics, beta-blockers (BBs), angiotensin-converting enzymes (ACEs) inhibitors (ACEls), calcium channel blockers (CCBs), and angiotensin II receptor blocker (ARB). Some other agents, such as renin inhibitors, centrally acting medications, alpha-adrenergic receptor blockers, and direct acting vasodilators are the additional hypertension drugs that are widely utilized for short-term treatment [7].

The use of antihypertensive drug may cause some side effects, both short- and long-term. Drowsiness, headache, edema or swelling, urine incontinence, tachycardia, sedation, dry mouth sensation, reduced renal perfusion, mild-moderate diarrhea, and bronchospasm are the most prevalent 
side effects [8]. Antihypertensive medicine use may also be a risk factor for cancer, according to a recent study, however the exact mechanism that causes carcinogenic consequences is unknown [9]. Another type of cancer also found to have a link with the usage of antihypertensive drug is breast cancer [10].

Breast cancer or breast carcinoma is the most common type of malignancy in women globally. It is also known to be the second leading cancer in the number of deaths among women annually. More than 250,000 women with invasive breast cancer in the USA are diagnosed each year [11]. Breast cancer also led to the deaths of 520 men and 42,170 women in a recent study in the United States [12]. Patients' median survival from first relapse was 17 months, indicating that it is a lifethreatening disease [13].

The link between antihypertensive drug use and the risk of breast cancer has piqued researchers' interest since 1990. Recent findings on the relation between antihypertensive drug use and the risk of breast cancer have been contradictory. BBs, CCBs, and diuretics have been associated to an increased risk of breast cancer in several studies [1], [2], [3], [4]. Meanwhile, taking an ACE inhibitor or an ARB has been linked to a higher or lower risk of breast cancer [14], [15].

Based on this, there are differences in results that do not produce generalized information. That is the opportunity to get answers to these differences. This is the first review so far to our knowledge that addresses the risk of antihypertensive medicines specific to breast cancer. As a response, to compare each type of antihypertensive medicines as a risk factor for breast cancer, we did a systematic review and meta-analysis of current evidence.

\section{Methods}

\section{Literature search}

PubMed, ScienceDirect, and Google Scholar were several databases combed for articles up through the last November 2020. The formula search employed Boolean "AND" or "OR" with "antihypertensive", "antihypertensive", "antihypertensive drugs", "breast cancer", "risk", "case control", and "cohort" keywords.

\section{Selection of the studies}

Studies included must meet the following criteria such as: (1) The result reported association of antihypertensive drugs use linked to the incidence of breast cancer patients; (2) the research calculated and announced on the relative risk of breast cancer using variable such as the odds ratio (OR 95\%); (3) crosssectional, cohort, and case-control study design; and (4) English-language studies. The study selection, quality evaluation, and data extraction were all done independently by three reviewers. The issue between the three reviewers was settled by consensus among the fourth and fifth reviewers. This study was designed using the Preferred Reporting Items for Systematic Review and Meta-Analysis (PRISMA) guideline guidelines [16].

\section{Measurement of the studies quality}

Newcastle Ottawa Scale was used to measure the quality of studies. This instrument has three components: Patient selection (four points), group comparability (one point), and exposure determination (one point) (three points). Measurement in the selection components includes: Proper case definition, case representativeness, control group selection, and definition. Measurement in the comparability components includes: Research controls for the most and extra factor. Measurement in the exposure domain includes: Exposure determination, method of cases and controls determination, and rate of nonresponse. The overall score varied from 0 (worst) to 8 (best). The overall quality was rated as good (final score $\geq 7$ ), moderate (final score $\geq 5$ until $<7$ ), or poor (final score $\leq 4$ ).

\section{Extraction of the studies data}

Using the predefined procedure, three reviewers retrieved the baseline characteristics, exposures, and outcomes of included studies independently. The initial name of author, publication year, design of research, the country, and the amount of people that participated (group of case and control) were all gathered. The length of each drug's therapy (diuretics, CCB, BB, ACEI, and ARB) was also retrieved. We e-mail the associated author when studies did not provide enough information to extract the data; however, we were unable to obtain further data using this technique since the associated author did not have the data information to begin with. We eliminated these studies from further quantitative analysis because we were unable to get the necessary data after trying to contact the associated authors.

\section{Data analysis}

The adjusted estimates of the risk of antihypertensive medication use between breast cancer patients were the study's primary outcome. The best-adjusted OR with $95 \%$ confidence interval $(\mathrm{Cl})$ was utilized. The Q-test was used to measure heterogeneity with a significance set at $p<0.10$. The Egger test was used to measure publication bias, with significance set at $p<0.05$. 


\section{Results}

\section{Literature search}

During the initial search 1239 studies were identified. The reference review included three additional articles [3], [17], [18] Three hundred and thirty-one articles are suitable for review following examination of the titles and abstracts. For restricted access, there are 189 sections excluded and nine duplicate items removed. One hundred and forty-two full text sections have been eligible for access. Thirteen papers were obtained in the qualitative synthesis. Thirteen articles are suited for quantitative summarization (metaanalysis). This literature search process is based on a modified PRISMA flow chart (Figure 1).

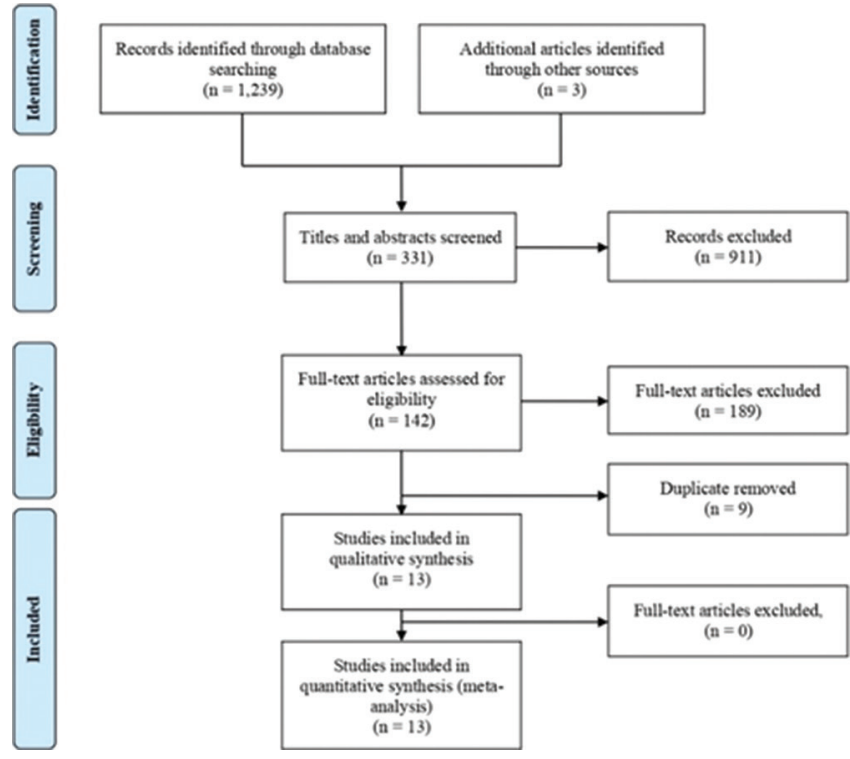

Figure 1: PRISMA flow diagram (modified)

\section{Study characteristics}

Table 1 provides an overview of the details from the 14 studies included. All studies were published in English. Two were prospective cohort studies and 11 were case-control studies. Six studies in the U.S., five in Europe, and two in Taiwan were conducted. The sample scales ranged from 654 to 747,085 , with 885,590 participants and 352 to 149,417 cases of breast cancer, with a total of 185,626 . Of these studies, eight had diuretic, CCB and BB results, seven were provided for ACEls and five were provided for ARBs. Evaluations of the drug use between studies have not been consistent; reviews of prescription and questionnaires have been most used.

\section{Data synthesis}

Atotal of 13 studies [2], [3], [4], [6], [15], [17], [18], [19], [20], [21], [22], [23], [24], consisting 185,626 patients with breast cancer and 699,964 control sample were included in our study. Of those, the correlation between AHT (diuretics, CCB, BB, ACEls, or ARBs) use and the risk of breast cancer was identified in five studies only [3], [4], [6], [21], [23]. A further eight studies failed to clarify the risk [2], [15], [17] [18, [19], [20], [22], [24]. Our calculation showed (Figure 2a) that the risk of antihypertensive drug was significantly different in overall analysis $(\mathrm{OR}=0.59,95 \% \mathrm{Cl}=0.42-0.83, \mathrm{p}=0.003)$. Moreover, in ARBs user sub-group, we included five studies [2], [6], [15], [19], [21] consisting of 39.503 breast cancer patients and 372,037 control sample. Our results found (Figure 2f) that significant different of antihypertensive drug among breast cancer patient was observed $(\mathrm{OR}=1.47,95 \% \mathrm{Cl}=1.02-2.11 \mathrm{p}=0.04)$. Our pooled data (Figure 2b-e) confirmed that the antihypertensive drug in the other drug subgroup did not differ in any significant way in breast cancer patients

Table 1: Study characteristics in our analysis

\begin{tabular}{|c|c|c|c|c|c|c|}
\hline \multirow[t]{2}{*}{ Author and Year } & \multicolumn{2}{|c|}{$\begin{array}{l}\text { Antihypertensive } \\
\text { Drug User }\end{array}$} & \multirow[t]{2}{*}{ Country } & \multirow[t]{2}{*}{ Study Design } & \multirow[t]{2}{*}{ Main Results } & \multirow[t]{2}{*}{ Quality } \\
\hline & $\mathrm{BC}$ & $\mathrm{N}$ & & & & \\
\hline Meier et al. 2000 & 1139 & 17861 & United Kingdom & Case control & $\begin{array}{l}\text { The risk of developing breast cancer is affected by no association in the long-term use of } \\
\text { ACE inhibitors or CCBs }\end{array}$ & Good \\
\hline Li et al. 2003 & 975 & 1982 & USA & Case control & $\begin{array}{l}\text { Particular types of antihypertensive medications (immediate-release CCBs and certain } \\
\text { diuretics) increase the risk of breast carcinoma among older women }\end{array}$ & Moderate \\
\hline $\begin{array}{l}\text { Gonzalez-Perez et al. } \\
2004\end{array}$ & 3708 & 23708 & United Kingdom & Cohort & $\begin{array}{l}\text { Anti-hypertensive drugs and breast cancer risk are not associated. Captopril in the same } \\
\text { line was not associated with a lower risk of breast cancer, though it cannot be safely ruled } \\
\text { out a small reduction in risk for long-term use }\end{array}$ & Good \\
\hline Largent et al. 2006 & 172 & 654 & USA & Case control & $\begin{array}{l}\text { Use of other blood pressure medications was not found to be associated with breast cancer } \\
\text { risk. These results support a positive link among women aged } 50-75 \text { years between the } \\
\text { treatment of hypertension, diuretic use, and breast cancer risk }\end{array}$ & Good \\
\hline Davis and Mirick 2007 & 547 & 1247 & USA & Case control & $\begin{array}{l}\text { The use of calcium channel blockers (CCBs) associated a slightly increased risk of breast } \\
\text { cancer, but no trend was associated with increasing duration or repetition of use. }\end{array}$ & Moderate \\
\hline Coogan et al. 2008 & 5989 & 11493 & USA & Case control & The use of diuretics does not increase breast cancer risk & Good \\
\hline Hallas et al. 2012 & 19947 & 332623 & Denmark & Case control & The association between ARB/ACEI use and cancer are weak & Good \\
\hline Botteri et al. 2013 & 74 & 800 & Italy & Cohort & $\begin{array}{l}\text { A significantly decreased risk of recurrence, metastasis, and death related to BC was } \\
\text { associated with the consumption of BB }\end{array}$ & Good \\
\hline Li et al. 2013 & 1960 & 2851 & USA & Case control & $\begin{array}{l}\text { In particular, long-term use of calcium canal blockers is associated with the risk of breast } \\
\text { cancer }\end{array}$ & Good \\
\hline Leung et al. 2015 & 6463 & 25450 & Taiwan & Case control & $\begin{array}{l}\text { In the study was found beta-1 selective blocker and CCBs have association with breast } \\
\text { cancer risk }\end{array}$ & Good \\
\hline Chen et al. 2015 & 352 & 1013 & USA & Case control & $\begin{array}{l}\text { A second primary contralateral breast cancer risk was not associated with an } \\
\text { antihypertensive class, including calcium channel obstruction agents, } \beta \text { blockers, ACE } \\
\text { inhibitors, and diuretics }\end{array}$ & Moderate \\
\hline Gómez-Acebo et al. 2016 & 1736 & 3631 & Spanish & Case control & The long-term usage of CCBs was associated with certain types of breast cancer & Good \\
\hline Chang et al. 2016 & 9397 & 46985 & Taiwan & Case control & $\begin{array}{l}\text { There were no significant association of using hypertension medication with the breast } \\
\text { cancer risk }\end{array}$ & Moderate \\
\hline
\end{tabular}




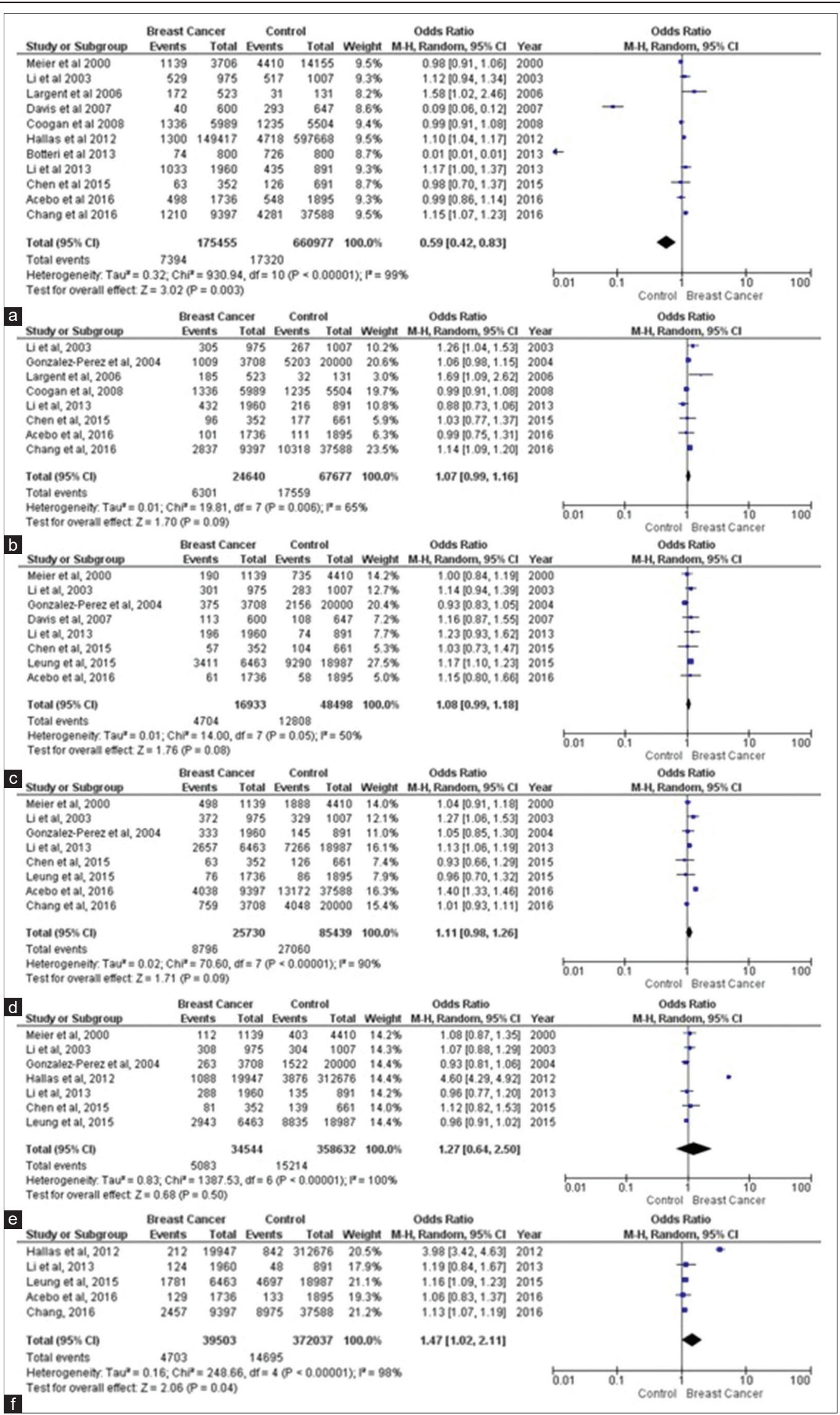

Figure 2: Forest plot of antihypertensive drug among breast cancer patient. (a) Overall analysis. (b) Diuretics user sub-group. (c) Calcium channel blockers user sub-group. (d) Beta-blockers user sub-group. (e) Angiotensin-converting enzymes inhibitors user sub-group. (f) Angiotensin II receptor blockers user sub-group 
$(\mathrm{OR}=1.07,95 \% \mathrm{Cl}=0.99-1.16, \mathrm{p}=0.09)$ in diuretics user, $(\mathrm{OR}=1.08,95 \% \mathrm{Cl}=0.99-1.18, \mathrm{p}=0.08)$ in CCB user, $(O R=1.11,95 \% \mathrm{Cl}=0.98-1.26, p=0.09)$ in $\mathrm{BB}$ user, and $(\mathrm{OR}=1.27,95 \% \mathrm{Cl}=0.64-2.50$, $p=0.50$ ) in ACEls user. Table 2 summarizes how the antihypertensive drug risk is correlated and the effect estimate is estimated in patients with breast cancer.

\section{Heterogeneity and publication bias}

The Q-Test was used to evaluate evidence of heterogeneity. Our analysis showed that overall analysis and a whole subgroup of drug user's demonstrated heterogeneity $(p<0.10)$. The random model of the effect was therefore used to determine the correlation and the estimate of effect. In addition, possible biases in the publication of the Egger test have been assessed. Our analysis showed that the BB subgroup and ACEI/ ARB subgroup $(p<0.05)$ have identified a possible bias in publication. We found no publication bias in diuretics and CCB subgroups. Table 2 describes the summary of the heterogeneity of the study and its possible publication.

\section{Discussion}

Breast cancer is sometimes diagnosed with concurrent comorbidities, such as hypertension, heart disease, diabetes, and arthritis. This condition also correlates with their vulnerability related age. Thus, breast cancer patients' prediagnostic health status in middle and age groups may affect tumor prognosis and treatment decisions. Several studies established that age and comorbidity strongly influence therapeutic decisions and were associated with less aggressive cancer therapy and that older women were less likely to have extensive pretreatment [25]. Meanwhile, antihypertension drugs were known to influence the prognosis of breast cancer patients. In addition, studies about hypertension drugs-related breast cancer still have a lot of contradictory results. A study with 13 consisting of 185,626 breast cancer patients and 699,964 control samples shows that antihypertensive drugs (diuretics, $\mathrm{CCB}, \mathrm{BB}$, and ACEls) are not significant for the risk of breast cancer. However, we found that ARBs have a weak potential in the risk of breast cancer. Our overall findings showed different results with a metaanalysis of randomized clinical trials of antihypertensive therapy that showed no increased cancer risk with the use of antihypertensive therapy [26]. In another study, there was no evidence about the association between CCB use and the increased risk of breast cancer, which is in line with some studies included in this meta-analysis [20], [22], [27] On the opposite side, another study found a significant relationship between long-term use of CCB with breast cancer and the differences might be because of the duration of $\mathrm{CCB}$ use in the samples [28]. About the BBs, the study before has the same result as our study that found BB is not associated with improved clinical outcomes in women with breast cancer [29]. However, another study found that BBs can reduce the risk of breast cancer recurrence [30].

Diuretic, as the treatment of hypertension, was also significantly associated with breast cancer risk [3]. Li et al. conducted a detailed study on antihypertensive medications and found thiazide and potassium-sparing diuretics, but not loop diuretics, to be associated with a modest increase in breast cancer risk postmenopausal women aged 65-79 years. In the present study, it cannot be ruled out that diuretic use was due to the underlying condition of hypertension, or vice versa [4]. CCBs have been used for so long as one of the hypertension drug categories. It was hypothesized to lead to the proliferation of the cells and tumor growth [31]. Li et al. study was established consistently with two previous meta-analyses in 2014 , indicating no carcinogenic effect of CCB on breast cancer [27], [28] A comprehensive review showed that CCBs are

Table 2: Summary of risk factors of antihypertensive drugs among breast cancer patients

\begin{tabular}{|c|c|c|c|c|c|c|c|c|c|c|c|c|}
\hline \multirow[t]{2}{*}{ Risk Factor } & \multirow[t]{2}{*}{ Variable } & \multirow[t]{2}{*}{ NS } & \multirow[t]{2}{*}{ Model } & \multicolumn{2}{|c|}{ Breast Cancer } & \multicolumn{2}{|c|}{ Control } & \multirow[t]{2}{*}{ OR } & \multirow[t]{2}{*}{$95 \% \mathrm{Cl}$} & \multirow[t]{2}{*}{$\mathrm{pH}$} & \multirow[t]{2}{*}{$\mathrm{pE}$} & \multirow[t]{2}{*}{$\mathrm{p}$} \\
\hline & & & & TS & Value (\%) & TS & Value (\%) & & & & & \\
\hline \multirow[t]{3}{*}{ Diuretics } & & 3 & & & & & & & & & & \\
\hline & $<5$ years & & Random & 894 & 354 (39.60) & 502 & $191(38.04)$ & 0.82 & $0.50-1.39$ & 0.019 & 0.386 & 0.473 \\
\hline & $\geq 5$ years & & Random & 894 & $540(60.40)$ & 502 & 311 (61.96) & 1.15 & $0.72-1.84$ & 0.040 & 0.333 & 0.545 \\
\hline \multirow[t]{3}{*}{ ССВ } & & 3 & & & & & & & & & & \\
\hline & $<5$ years & & Fixed & 477 & 237 (49.69) & 801 & 467 (58.30) & 0.98 & $0.75-1.27$ & 0.150 & 0.223 & 0.893 \\
\hline & $\geq 5$ years & & Fixed & 477 & $240(50.31)$ & 801 & $334(41.70)$ & 1.02 & $0.78-1.31$ & 0.150 & 0.223 & 0.893 \\
\hline \multirow[t]{3}{*}{ B-Blockers } & & 4 & & & & & & & & & & \\
\hline & $<5$ years & & Fixed & 932 & $444(47.64)$ & 1798 & 973 (54.11) & 0.91 & $0.77-1.09$ & 0.840 & $<0.0001$ & 0.325 \\
\hline & $\geq 5$ years & & Fixed & 932 & $488(52.36)$ & 1798 & $825(45.89)$ & 1.09 & $0.92-1.30$ & 0.840 & $<0.0001$ & 0.325 \\
\hline \multirow[t]{3}{*}{ ACEls } & & 3 & & & & & & & & & & \\
\hline & $<5$ years & & Fixed & 513 & $281(54.80)$ & 630 & 377 (59.85) & 1.18 & $0.91-1.54$ & 0.304 & 0.102 & 0.202 \\
\hline & $\geq 5$ years & & Fixed & 513 & $232(45.22)$ & 630 & $253(40.15)$ & 0.84 & $0.64-1.09$ & 0.304 & 0.102 & 0.202 \\
\hline
\end{tabular}


associated with an enhancement of the risk of tumor development by reducing the levels of intracellular $\mathrm{Ca}^{2+}$ as a potential signal for cellular apoptosis [32]. Its basic assumption was directly contradicted with the several laboratories finding that demonstrating an elevation in cytoplasmic $\mathrm{Ca}$ is not required for either the activation of DNA endonucleases or apoptosis mechanism [33]. An apoptosis mechanism could be reproducibly initiated by a decrease in cytoplasmic $\mathrm{Ca}^{2+}$ levels [34]. Even though not well understood, it has been proposed that the low level of $\mathrm{Ca}^{2+}$ could avoid cation-mediated charge neutralization of DNA, thus resulting in apoptosis stimulation. Chelators of intracellular $\mathrm{Ca}^{2+}$ and the calmodulin inhibitor-7 have been shown that increased the apoptosis rate in neutrophils virtually. Cytoplasmic $\mathrm{Ca}^{2+}$ deficiency in the cells could be rescued from apoptotic cell death with the use of $\mathrm{Ca}^{2+}$ ionophores or $\mathrm{Ca}^{2+}$ channel agonists [35]. Lack of an apparent requirement for elevated $\mathrm{Ca}^{2+}$ levels in the cytoplasm during apoptosis suggests that cation sensitive DNA endonucleases activation may require only in deficient levels of $\mathrm{Ca}^{2+}$ or may not even be an essential process. This observation could help to rationalize why CCBs have inconsistent effects on apoptosis [36].

Most preclinical studies have shown that BBs inhibit multiple cellular pathways involved in breast cancer progression and tumor growth, including cell proliferation, angiogenesis, the metastatic process, and tumor immune responses [37], [38], [39], [40], [41]. In vitro studies reported that BBs have significantly decreased $\mathrm{Ki}-67$ expression, phosphorylation of multiple mitogenic activated protein kinases, and cyclic adenosine monophosphate (cAMP) responsive element-binding protein (CREB). BBs also increased phosphorylation of protein kinase $B(P K B)$, glycogen synthase kinase 3 (GSK3), and p53 expression [39], [40]. In vivo studies also reported the same outcomes related to BBs effect on breast cancer progression through inhibition or antagonism of the beta-adrenergic receptor $(\beta-A R)$ signaling. $\beta-A R$ is previously known to promote and increase breast tumor growth, breast cancer metastases, angiogenesis through VEGF, upregulation of both expression of macrophagederived factors (COX2, MMP-9, and VEGF), and matrix metalloproteinase (MMP), especially MMP-2 [41], [42].

Some studies on the clinical phase also reported that BB consumption before diagnosis presented a significantly lower metastasis rate in breast cancer patients [42], [43]. On another side, only a few studies have reported associations between BBs and breast cancer [2], [19]. Thus, our findings are consistent with the most previous studies that found no significant difference of BB drug among breast cancer patients [42], [43]. However, we were unable to report the relationship between the use of particular types of BBs and breast cancer patients since most of the studies do not reported the subclass of BB drugs used in the cases. Only one case-control study in the USA that further classified BB drugs into short and long-acting
$\mathrm{BB}$ and found that the OR of short-acting higher than long-acting BB used [4].

\section{Conclusions}

Hypertension being one of breast cancer comorbidity and influence their quality of life. Antihypertension drug weather prognosis or the risk of breast cancer remains the contradiction result. Regarding to our finding in 13 studies established statistical significant the association between antihypertension drug and breast cancer.

\section{Acknowledgments}

We would like to express our gratitude and high honors to the RISE-Search Oncology Group for assisting in a number of technical matters in the preparation of this manuscript.

\section{Ethical Approval and Consent to Participate}

Ethic approval and informed consent were not required in our study.

\section{Limitations}

Our meta-analysis had several limitations. Limit to enroll all eligible studies due to article access, difficulty in summarizing data due to difference data presentation data in several studies, we could not evaluate the others variable such as risk factors that might affect the intervention duration and outcome, differences in the classification of intervention durations mean that we may not have sufficient power to accurately estimate the risks associated with long-term drug use.

\section{Authors Contributions}

Idea/concept: SW. Design: SW and IAWA. Control/supervision: SW and JKF. Data collection/ processing: ADFW, AABPI, and IGKAS. Extraction/ Analysis/interpretation: PAW, AABPI, IGKAS, SW, and IPYP. Literature review: SW, JKF. Revision and proof 
reading: DMW, IGPS, PATA, IWS, and AAWL. Writing the article: PAW, AABPI, IGKAS, SW, and IAWA. Critical review: all authors have critically reviewed and approved the final draft and are responsible for the content and similarity index of the manuscript.

\section{References}

1. Biggar RJ, Andersen EW, Wohlfahrt J, Melbye M. Spironolactone use and the risk of breast and gynecologic cancers. Cancer Epidemiol. 2013;37(6):870-5. https://doi.org/10.1016/j. canep.2013.10.004

PMid:24189467

2. Chang $\mathrm{CH}$, Chiang $\mathrm{CH}$, Yen CJ, Wu LC, Lin JW, Lai MS. Antihypertensive agents and the risk of breast cancer in women aged 55 years and older: A nested case-control study. J Hypertens. 2016;34(3):558-66. https://doi.org/10.1097/ hjh.0000000000000813

PMid:26818924

3. Largent JA, McEligot AJ, Ziogas A, Reid C, Hess J, Leighton N, et al. Hypertension, diuretics and breast cancer risk. J Hum Hypertens. 2006;20(10):727-32. https://doi.org/10.1038/ sj.jhh. 1002075

PMid:16885996

4. Li Cl, Malone KE, Weiss NS, Boudreau DM, CushingHaugen KL, Daling JR. Relation between use of antihypertensive medications and risk of breast carcinoma among women ages 65-79 years. Cancer. 2003;98(7):1504-13. https://doi. org/10.1002/cncr.11663

PMid:14508839

5. World Health Organization. A Global Brief on Hypertension: Silent Killer, Global Public Health Crisis. Geneva: World Health Organization; 2013.

6. Li Cl, Daling JR, Tang MT, Haugen KL, Porter PL, Malone KE. Use of antihypertensive medications and breast cancer risk among women aged 55 to 74 years. JAMA Intern Med. 2013;173(17):1629-37. https://doi.org/10.1001/ jamainternmed.2013.9071

PMid:23921840

7. Oster JR, Materson BJ, Perez-Stable E. Antihypertensive medications. South Med J. 1984;77(5):621-30. https://doi. org/10.1097/00007611-198405000-00020

8. Jackson RE, Bellamy MC. Antihypertensive drugs. BJA Educ. 2015;15(6):280-5.

9. Battistoni A, Volpe M. Recent warnings about antihypertensive drugs and cancer risk: Where do they come from? Eur Cardiol. 2020;15:e21. https://doi.org/10.15420/ecr.2019.21 PMid:32419852

10. Chen L, Chubak J, Boudreau DM, Barlow WE, Weiss NS, Li CI. Use of antihypertensive medications and risk of adverse breast cancer outcomes in a SEER-medicare population. Cancer Epidemiol Biomarkers Prev. 2017;26(11):1603-10. https://doi. org/10.1158/1055-9965.epi-17-0346 PMid:28807926

11. Watkins EJ. Overview of breast cancer. JAAPA. 2019;32(10):13-7.

PMid:31513033

12. American Cancer Society. Cancer Facts and Figures 2020 United States: American Cancer Society; 2020.

13. Kim H, Choi DH, Park W, Huh SJ, Nam SJ, Lee JE, et al.
Prognostic factors for survivals from first relapse in breast cancer patients: Analysis of deceased patients. Radiat Oncol J. 2013;31(4):222-7. https://doi.org/10.3857/roj.2013.31.4.222 PMid:24501710

14. Devore EE, Kim S, Ramin CA, Wegrzyn LR, Massa J, Holmes MD, et al. Antihypertensive medication use and incident breast cancer in women. Breast Cancer Res Treat. 2015;150(1):219-29. https://doi.org/10.1007/ s10549-015-3311-9

PMid:25701121

15. Hallas J, Christensen R, Andersen M, Friis S, Bjerrum L. Long term use of drugs affecting the renin-angiotensin system and the risk of cancer: A population-based case-control study. Br J Clin Pharmacol. 2012;74(1):180-8. https://doi. org/10.1111/j.1365-2125.2012.04170.x PMid:22243442

16. Liberati A, Altman DG, Tetzlaff J, Mulrow C, Gøtzsche PC, loannidis JP, et al. The PRISMA statement for reporting systematic reviews and meta-analyses of studies that evaluate healthcare interventions: Explanation and elaboration. BMJ. 2009;339:b2700. https://doi.org/10.1136/bmj.b2700 PMid:19622552

17. González-Pérez A, Ronquist G, García Rodríguez LA. Breast cancer incidence and use of antihypertensive medication in women. Pharmacoepidemiol Drug Saf. 2004;13(8):581-5. https://doi.org/10.1002/pds.910

PMid: 15317040

18. Coogan PF, Strom BL, Rosenberg L. Diuretic use and the risk of breast cancer. J Hum Hypertens. 2009;23(3):216-8. https://doi. org/10.1038/jhh.2008.131

PMid: 18971940

19. Leung HW, Hung LL, Chan AL, Mou CH. Long-term use of antihypertensive agents and risk of breast cancer: A populationbased case-control study. Cardiol Ther. 2015;4(1):65-76. https:// doi.org/10.1007/s40119-015-0035-1

PMid:25657096

20. Chen L, Malone KE, Li Cl. Use of antihypertensive medications not associated with risk of contralateral breast cancer among women diagnosed with estrogen receptor-positive invasive breast cancer. Cancer Epidemiol Biomarkers Prev. 2015;24(9):1423-6. https://doi.org/10.1158/1055-9965. epi-15-0547 PMid:26084603

21. Gómez-Acebo I, Dierssen-Sotos T, Palazuelos C, PérezGómez B, Lope V, Tusquets I, et al. The use of antihypertensive medication and the risk of breast cancer in a case-control study in a Spanish population: The MCC-spain study. PLoS One. 2016;11(8):e0159672. https://doi.org/10.1371/journal. pone.0159672

PMid:27508297

22. Meier CR, Derby LE, Jick SS, Jick H. Angiotensin-converting enzyme inhibitors, calcium channel blockers, and breast cancer. Arch Intern Med. 2000;160(3):349-53. https://doi.org/10.1001/ archinte.160.3.349 PMid: 10668837

23. Davis S, Mirick DK. Medication use and the risk of breast cancer. Eur J Epidemiol. 2007;22(5):319-25. PMid:17487555

24. Botteri E, Munzone E, Rotmensz N, Cipolla C, de Giorgi V, Santillo B, et al. Therapeutic effect of $\beta$-blockers in triplenegative breast cancer postmenopausal women. Breast Cancer Res Treat. 2013;140(3):567-75. https://doi.org/10.1007/ s10549-013-2654-3

PMid:23912960

25. Yancik R, Wesley MN, Ries LA, Havlik RJ, Edwards BK, 
Yates JW. Effect of age and comorbidity in postmenopausal breast cancer patients aged 55 years and older. JAMA. 2001;285(7):885-92. https://doi.org/10.1001/jama.285.7.885 PMid: 11180731

26. Bangalore S, Kumar S, Kjeldsen SE, Makani H, Grossman E, Wetterslev $\mathrm{J}$, et al. Antihypertensive drugs and risk of cancer: Network meta-analyses and trial sequential analyses of 324, 168 participants from randomised trials. Lancet Oncol. 2011;12(1):65-82. https://doi.org/10.1016/ s1470-2045(10)70260-6

PMid:21123111

27. Chen Q, Zhang Q, Zhong F, Guo S, Jin Z, Shi W, et al. Association between calcium channel blockers and breast cancer: A metaanalysis of observational studies. Pharmacoepidemiol Drug Saf. 2014;23(7):711-8. https://doi.org/10.1002/pds.3645 PMid:24829113

28. Li W, Shi Q, Wang W, Liu J, Li Q, Hou F. Calcium channel blockers and risk of breast cancer: A meta-analysis of 17 observational studies. PLoS One. 2014;9(9):e0198220. https:// doi.org/10.1371/journal.pone.0105801

PMid:29791500

29. Li C, Li T, Tang R, Yuan S, Zhang W. $\beta$-blocker use is not associated with improved clinical outcomes in women with breast cancer: A meta-analysis. Biosci Rep. 2020;40(6):BSR20200721. https://doi.org/10.1042/bsr20200721

PMid:32436935

30. Zhao $Y$, Wang $Q$, Zhao $X$, Meng $H$, Yu J. Effect of antihypertensive drugs on breast cancer risk in female hypertensive patients: Evidence from observational studies. Clin Exp Hypertens. 2018;40(1):22-7. https://doi.org/10.1080/1 0641963.2017.1288736 PMid:29115847

31. Pahor M, Guralnik JM, Ferrucci L, Corti MC, Salive ME, Cerhan JR, et al. Calcium-channel blockade and incidence of cancer in aged populations. Lancet. 1996;348(9026):493-7. https://doi.org/10.1016/s0140-6736(96)04277-8 PMid:8757150

32. Whitfield JF. Calcium signals and cancer. Crit Rev Oncog. 1992;3(1-2):55-90. PMid: 1550862

33. Reynolds JE, Li J, Craig RW, Eastman A. BCL-2 and MCL-1 expression in Chinese hamster ovary cells inhibits intracellular acidification and apoptosis induced by staurosporine. Exp Cell Res. 1996;225(2):430-6. https://doi.org/10.1006/excr.1996.0194 PMid:8660932

34. Rodriguez-Tarduchy G, Malde P, Lopez-Rivas A, Collins MK Inhibition of apoptosis by calcium ionophores in IL-3-dependent bone marrow cells is dependent upon production of IL-4+.
J Immunol. 1992;148(5):1416-22.

PMid: 1538126

35. Whyte MK, Hardwick SJ, Meagher LC, Savill JS, Haslett C. Transient elevations of cytosolic free calcium retard subsequent apoptosis in neutrophils in vitro. J Clin Invest. 1993;92(1):446-55. https://doi.org/10.1172/jci116587

PMid:8392090

36. Mason RP. Calcium channel blockers, apoptosis and cancer: Is there a biologic relationship? J Am Coll Cardiol. 1999;34(7):1857-66.

PMid: 10588195

37. Barron TI, Sharp L, Visvanathan K. Beta-adrenergic blocking drugs in breast cancer:Aperspective review. TherAdv Med Oncol. 2012;4(3):113-25. https://doi.org/10.1177/1758834012439738 PMid:22590485

38. Peixoto R, de Lourdes Pereira M, Oliveira M. Beta-blockers and cancer: Where are we? Pharmaceuticals (Basel). 2020;13(6):105. https://doi.org/10.3390/ph13060105 PMid:32466499

39. Park SY, Kang JH, Jeong KJ, Lee J, Han JW, Choi WS, et al. Norepinephrine induces VEGF expression and angiogenesis by a hypoxia-inducible factor- $1 \alpha$ protein-dependent mechanism. Int $J$ Cancer. 2011;128(10):2306-16. https://doi.org/10.1002/ijc.25589 PMid:20715173

40. Avraham R, Benish M, Inbar S, Bartal I, Rosenne E, BenEliyahu S. Synergism between immunostimulation and prevention of surgery-induced immune suppression: An approach to reduce post-operative tumor progression. Brain Behav Immun. 2010;24(6):952-8. https://doi.org/10.1016/j.bbi.2010.03.010 PMid:20362661

41. Madden KS, Szpunar MJ, Brown EB. $\beta$-Adrenergic receptors $(\beta-A R)$ regulate VEGF and IL-6 production by divergent pathways in high $\beta$-AR-expressing breast cancer cell lines. Breast Cancer Res Treat. 2011;130(3):747-58. https://doi. org/10.1007/s10549-011-1348-y

PMid:21234673

42. Choy C, Raytis JL, Smith DD, Duenas M, Neman J, Jandial R, et al. Inhibition of $\beta 2$-adrenergic receptor reduces triplenegative breast cancer brain metastases: The potential benefit of perioperative $\beta$-blockade. Oncol Rep. 2016;35(6):3135-42. https://doi.org/10.3892/or.2016.4710

PMid:27035124

43. Parada-Huerta E, Alvarez-Dominguez TP, Uribe-Escamilla R, Rodriguez-Joya J, Ponce-Medrano JD, Padron-Lucio S, et al. Metastasis risk reduction related with beta-blocker treatment in Mexican women with breast cancer. Asian Pacific J Cancer Prev. 2016;17(6):2953-7.

PMid:27356717 